\title{
Group cohesiveness and poly-culturalism: The study of student nomads in Malang
}

\author{
Diah Karmiyati ${ }^{{ }^{*}}$, Clara Nidya Corsha ${ }^{1}$, and Muhammad Fath Mashuri ${ }^{1}$ \\ ${ }^{1}$ Universitas Muhammadiyah Malang \\ *Corresponding author: diah@umm.ac.id
}

KEYWORDS

Group Cohesiveness

Poly-culturalism

Students Nomads

\begin{abstract}
Students in Malang is derived from the background of a diverse culture. Students nomads have a community called the organization of the area. The interaction between cultures is very prone to conflict and friction that very harmful. The prevention of conflict can be done with poly-culturalism or the belief that each group has interacted with each other and provide a positive influence. But, the cohesiveness of the group owned by a regional organization as the internal strength of the group can be a barrier in the relationship between the organization of the area. The purpose of this study is to determine whether there is a correlation between group cohesiveness with poly-culturalism on student nomads in Malang. This research is quantitative research, using purposive sampling techniques. The research instrument used the Group Cohesiveness Scale and Poly-culturalism Scale. The results showed that there is a significant positive relationship between group cohesiveness and polyculturalism on student nomads in Malang. Group cohesiveness which is owned by the students of the nomads in Malang does not inhibit the formation of poly-culturalism.
\end{abstract}

(c) The Author(s) 2021

\section{INTRODUCTION}

Malang is a city of students, so that Malang became one of the goals of the students from various cities of Indonesia to continue their education. Malang has some of the best universities, which became the target of students from various cities in great Malang, even outside the island of Java in general. Students gain knowledge in Malang is derived from the area, tribe, race, ethnic to a diverse culture, it is this cause there is a diversity of culture in Malang. Each of the students who come from outside the Malang City has a regional association organization of its own that is an organization or association to overshadow the students with the background area of the same origin, for example, a student who comes from the province of West Kalimantan involved in the organization of Family area with Students from West Kalimantan (KPMKB), a student from Madura involved in the organization of the regional association of Students of Madura (IMAMA), students who come from the province of Bengkulu involved in the organization of local Family Ties Student Bengkulu Malang (IKMBM) and many more local organizations located in Malang. The organization of this area was often met in some cultural activities, such as Festival Culture Village that held by the University of Brawijaya. The Festival has become a place for local organizations to introduce a variety of cultural uniqueness of the region.

The interaction of the people or groups with different cultural backgrounds is not a new thing that is encountered in Malang. The competition is sometimes inevitable from the life of the ethnically diverse each group featuring the group and threw a deficiency or alleged negative to the other groups. The interaction between ethnic or groups of students often leads to misunderstandings in the receive and convey information from two sides. It was motivated by the occurrence of the process of communication between the students' groups.

The conflict between race, ethnicity, and religion had occurred in Indonesia. In 1999 there was a Perang Ambon, which is also known as the bloody conflict because it killed thousands of lives. The cause of this war is quite simple, preceded by a dispute between two youth and bring the two religious and community groups into it. In the year 2001 also a tragedy occurs in Sampit. Tragedi Sampit is a bloody conflict that occurs between the Dayak and the citizens of migrants from Madura. This conflict occurred due to the shift between the two great tribes that resulted in the disruption of the stability and security of the nation; even hundreds of people were homeless, and not a few were stretched their life.

Conflict involving community groups also occurred in Malang, namely the clash between students from Papua incorporated in the Aliansi Mahasiswa Papua (AMP) with the people of Malang. Another conflict involving ethnicity happened between the citizens of Malang and the students of East Nusa Tenggara due to perceived discrimination.

Conflict will always have a negative impact on various areas, both the direct impact that can be felt the moment was or the impact that will be felt after the conflict ended. Peace efforts begin with improving the objectivity and fairness of individuals or groups. Interact with each other positively influences both, better in looking at the group of tribal values, beliefs, and culture. 
Poly-culturalism is the belief that racial or ethnic groups that are different constantly interact exchange and mutual influence and has been associated with attitudes between positive and greater comfort with diversity (Rosenthal, L., Levy, S. R., Katser, M., \& Bazile, 2015). Polyculturalism, similar to multiculturalism in recognizing the importance of people with cultural backgrounds differences, focuses on the interaction between cultural groups that influence each other. The individual with the mindset poly-culturalism compared with those who have the mindset of multiculturalism are more willing to criticize their own culture (Tjipto, S., \& Bernardo, 2019). The more eager to interact between groups and have a more positive attitude to people from different cultures (Hong, Y.-y., Zhan, S., Morris, M. W., \& Martinez, 2016).

Another reason why poly-culturalism is interesting to learn is that can be unifying. Consciousness to interact with each other and have a positive outlook towards other groups owned by the poly-culturalism can prevent groups from the tension that comes when a group of mutually tangent, can even cultivate the awareness of the unity of the poly-culturalism is closely related to the willingness to accept the diversity. Occurs mainly in the immediate environment even individuals who believe in this ideology will not hesitate to criticize their own culture if it is true. In line with the previous statement, it states that poly-culturalism tends to be associated with willingness to direct contact between the group and the intention to behave positively with people from cultural minorities or foreigners also with groups of migrants (Tjipto, S., \& Bernardo, 2019). Also, poly-culturalism can cultivate an attitude of inter-group more positively by making people feel more connected with members of different groups (Rosenthal, L., \& Levy, 2012). Poly-culturalism is also associated with the belief in social equality among different groups of feeling more comfortable with the respect for diversity and interest to interact with people from different backgrounds (Rosenthal, L., \& Levy, 2010).

Poly-culturalism also focuses on how people live side by side to interact with each other and then take cultural influences from the various cultures (Morris, M. W., Chiu, C.-y., \& Liu, 2015). Believing the poly-culturalism students from diverse cultural backgrounds will affect each other through a willingness to interact and establish relationships with groups of different cultures and foster positive attitudes towards groups of different cultures. The way that the other part, other groups, other cultures have been connected as well as have interaction and influence each other and with the attitude of mutual acceptance and more positive towards other groups will have an impact on the comfort of diversity so that peace will be felt.

Group cohesiveness can be interpreted as an interest in interaction with the members who can give motivation to the members of the group (Hermawan, Y., \& Rstiana, 2019). Cohesiveness explains the individual interest to survive in the group. Students nomads in Malang are incorporated in an organized area as minorities and immigrants into the background of the students gathered with people from the same area.

Some studies mention the role of positive cohesiveness in a group. Mention that cohesiveness has a positive relationship with achievement motivation in an athletes sports team (football). This relationship indicates the positive group cohesiveness according to the athlete, the higher the achievement motivation of its vice versa (Sakdiah, H., \& Astuti, 2014). It means that the higher the cohesiveness of the group, the higher the achievement motivation in an athletes sports team. Group cohesiveness affects the increase in the morale of employees (Putriantini, 2012). Group cohesiveness also showed a positive relationship with organizational commitment, which means that the higher the cohesiveness, the higher the commitment of the organization [10].

Cohesiveness tends to be associated with the compactness of the group that cohesiveness gives a positive sense to the internal group. However, in his study of football, players mention that cohesiveness is strong in a team will bring up the in-group favouritism, which is a view that the team or group we are the best so that your opponent as outgroup is a threat to the group (Akbar, 2018). If in-group favouritism is valid and owned by the regional organization with the background of the culture of the region of origin of diversity, then it will show the degree of competition between local organizations as well as open spaces prejudice and assessment of an aggressive inter-regional organization. Each regional organization will assume that the organization of the region's best among the others and felt that the organization of the area from other regions is the rival of them. Such case can impede the course of the growth of poly-culturalism among local organizations, the understanding of poly-culturalism is identical to the low degree of prejudice between groups.

Research on poly-culturalism in Indonesia is still rarely done. The researchers found only a journal that explains the research on poly-culturalism with the population of a region in Indonesia. It was seen as less complete to represent Indonesia which consists of various tribes and ethnic groups spread across 33 provinces from Sabang to Merauke. Motivated by the lack of literature that describes the phenomenon of poly-culturalism in Indonesia, this is what the researchers are trying to find a new view related to polyculturalism in Indonesia.

This research aims to determine the effect of group cohesiveness to poly-culturalism on the students in Malang. This research can also provide benefits as an additional reference for the scientific field of social psychology and culture.

\section{METHOD}

This study used a quantitative approach. This approach is a type of study that will collect numerical data (numbers), which is then processed using statistical techniques (Azwar, 2007). The results of the data collection were conducted by distributing a research instrument in the form of scale. The design used in this research is correlational. It is meant to determine the relationship between variables (Sugiyono, 2016).

This sampling technique using purposive sampling is a sampling technique by providing considerations or specific criteria. The subjects in this study were 200 people with the following criteria: (1) Students nomads in Malang who are members of a regional organization, (2) Aged 1823 years. This age range with the reason that the age is an age productive of students, i.e. students in the first year to the fourth year lectures whose ages of 18-23 years are categorized into early adulthood as it is a period of an individual started to face events of the transition from 
adolescence; it can be an attempt of the discovery of selfidentity (Santrock, 2012). The search for identity also involves the environment or association of individuals and organizations area can be one of them.

In this research, there are two variables, Independent variable $(\mathrm{X})$ and dependent variable $(\mathrm{Y})$. In this study, the independent variable $(\mathrm{X})$ is the cohesiveness of the group, while the dependent variable $(\mathrm{Y})$ is a poly-culturalism.

Poly culturalism is the belief that groups or different ethnic already interact and affect each other without removing the peculiarities of each, which has been held continuously to the present. The research instrument using a scale of poly culturalism adapted from Levy and Rosenthal (2012) and amounted to 5 items of the statement, all of which is items favourable (Rosenthal, L., \& Levy, 2012). The indicators expressed in such a scale is about (a) group race (racial group), (b) ethnic (ethnic), and (c) the influence of inter-cultural groups (influence of culture intergroup). Subjects were asked to respond by selecting numbers 1 through 7. The choice of figure 1 represents the response of strongly disagree to the statement that given to figure 7 represents the response of strongly agree to the statement. After the reliability test through try out that has been done, the results obtained from the Alfa of 0,799 greater than 0.7. The correlation of the item total to be in the range of 0,409 until 0,680 that all items are declared valid because of its value exceeding 0.3 .

Group cohesiveness which is intended in this study, is the interest of the individual to survive in the group by building familiarity and give each other support for the continuation of the group. The cohesiveness scale used in this study consisted of 32 items from the 40 items (Wahidah, 2013). The item uses four alternative answers in the form of multiple-choice, i.e. SS (strongly agree), S (agree), TS (disagree) and STS (strongly disagree). Scoring moves from 4 (SS) to 1 (STS) for the category of favourable and a score that moves from 1 (STS) to 4 (SS) to category unfavourable. The items in the scale group cohesiveness are compiled based on the aspects to measure the group's cohesiveness that was stated by Zanden (Wahidah, 2013). Based on the test, the validity of the 32 items is accepted because it has the power of discrimination item satisfactory is located at the top of 0.30 and move between 0,307 up with 0,692 scales is also said to be reliable as it has an alpha value of 0,863 .

There are three main stages in this study. First, the researchers started with the deepening of the material through theoretical studies. Then the researchers conducted the preparation and development of the measuring instrument used are based on aspects of the research variables. Researchers try out against the research instrument to test the instrument's feasibility based on the validity and reliability. Try out is done to 50 students in Malang who joined a regional organization. Then the researchers conducted the data analysis by using Statistical Package for Social Science (SPSS) 21 to determine the validity and reliability of items on the instrument.

\section{RESULTS AND DISCUSSION}

The result of this research showed that there is a positive relationship between group cohesiveness with polyculturalism on the student nomads in Malang. This research aims to prove whether there is a negative relationship between group cohesiveness with the formation of poly-culturalism on the student nomads who are members in the organization areas in Malang. This study was conducted on 250 subjects where the 124 subjects were male and 126 of the subject were female. The results showed that there is a positive relationship between group cohesiveness and poly-culturalism on the student nomads in Malang.

Concluded that group cohesiveness will trigger the onset of competition, prejudice and unwillingness to do the interaction between groups that may hinder the emergence of poly-culturalism is not in line with the results of this study (Akbar, 2018). In-group favoritism on the groups mentioned in the previous research does not appear on the student nomads as a member of the regional organization in Malang, so as not to trigger prejudice, negative assessment of inter-regional organizations as well as not to cause unwillingness to interact with the organization of the other areas that can hinder the poly-culturalism among students in Malang.

There are some factors that affect the results of the research show that the cohesiveness of the group did not show a negative correlation with poly-culturalism but the presence of a positive correlation. The first factor that allows it to be the reason that the cohesiveness of the group on the organization of the area in Malang does not bring up the in-group favouritism, as a group of local organizations. It is not placed in a competitive situation, which is required for competing for the title as the winner in a competition like that occurs on the subject in several previous studies. This makes the little possibility for the emergence of a sense of competition among local organizations that can inhibit the sense of unity organization. The students of the nomads do not compete with a group of local organizations. However, members of the organization make a good relationship with all of the students from diverse regions.

Another factor that becomes the reason is the norms and values espoused by a group of local organizations in view of its relationship with another group. The values and norms of life lead to a positive relationship with the group organization in other areas, such as establishing a relationship and maintaining good relations with other groups and a positive view of the group organization in other areas. The value of life is agreed upon by members of the organization of the area to then be used as a reference in the act against another group. The similarity of attitudes and values among the members of the group is the strongest factor in the cohesiveness of the group (Ibrahim, Z., Rahman, N. R., \& Johar, 2019). The members of the group will tend to conform and follow the norms in the group (Pratama, 2009). Then, it is possible that the cohesiveness of the group does not become an obstacle to the poly-culturalism but can support poly-culturalism if the group is applying the norms and values as a positive value in looking at the relationship with other groups. Then directed on the awareness of tolerance among the group organization of other areas and feel of unity as a fellow of the nation of Indonesia. Solidarity is formed which a priority of ideals and the common interest of the group above personal interests (Saidang, 2019). In this case, the identity of the group that has been agreed will be shared identity and self-identity member of the group cohesiveness.

The other factor that influences the poly-culturalism present among the students of nomads in Malang, because the group of local organizations have agreed that as a group 
of local organizations not only have one identity that is as a student of the nomads, but must have a lot of categories of identity that is more inclusive. In the daily life of students between local organizations who have a different cultural background have interacted with each other, and even requires to cooperate in the life of the lectures, so the students with cultural backgrounds differences no longer label themselves only as part of a regional organization, but more than that has had the identity of others, namely as a student and has become a part of one of the universities in Malang. This view presents the understanding that the other student and I is the same and next to each other in daily life as a student. This understanding will be owned and applied together as members of a group that is cohesive to open a broad social accompanied by intense interaction with people from different cultures.

This study found that there is a difference between poly-culturalism and group cohesiveness on student nomads in Malang if viewed by the length of the join with the organization of the area. This is in line with the opinion of Robbins that one of the factors that determine the degree of viscosity of a group is the length of time to be together in a group because the longer it is in a group will make the members will be getting to know each other and can cause tolerance between members of the group (Bachroni, 2011).

In addition, it also found that there are different polyculturalism based on the region of the area. The demographic data that were examined in this study found that there are several local organizations that have polyculturalism low especially dominated by a group of local organizations that originated from the region of eastern Indonesia. This group voted exclusively to the outside environment due to several things, including some of the events of a clash that occurred between the students of the east with the community some time ago, thus giving birth to the prejudice among the people that make the community does not give a good reception to this group. Poor reception, as well as the lack of a space, to discuss in solving problems that had occurred, then the group became reluctant to open up to the outside community. This state is thought to also occur due to the impact as a group that is a minority. Picture and opinions that often arise in the discussion of the majority and the minority is that minority groups feel that their existence is threatened due to some discrimination from the majority group (Umihani, 2019). This allows the cause of the reluctance of the minority group to open in the which is the majority group.

This study has limitations because this research was in the form of correlational, so just find the results in the form of the relationship between variables and cannot examine in-depth the cause and effect between the two variables. Nevertheless, this study also has the advantage that it can be used as one of the references in the realm of psychology and culture because this research can be said as the research is relatively new. The findings of the study inform that the cohesiveness of the group does not preclude the individual from accepting differences, be open with each other and interact with each other as well as give attitude and a positive outlook towards other groups.

\section{CONCLUSION}

The results of the study found that students nomads who have the cohesiveness to the group organization of the area do not make the students reluctant to establish a relationship with the group organization to other areas, and the cohesiveness which exists in a group of local organizations able to direct members of the group to establish relationships with other groups and bring up poly-culturalism.

This study obtained the fact that the cohesiveness of the group that is owned by a group of local organizations student nomads in Malang does not become a threat to the emergence of poly-culturalism even have a positive influence in the present poly-culturalism. This makes polyculturalism can be improved through increased group cohesiveness, but with a few things that need to be considered, namely, the values that are contained in the group need to be addressed first. Things that need to be considered further by the government as authorities are messages about unity in diversity.

In addition, the activities that brought the concept of cultural exchange that aims to get to know each other a wide variety of cultures and activities, the relationship between a group of local organizations increasingly propagated, so awareness of diversity is increasingly embedded in student nomads in Malang. The implications of this research, further research can be conducted a similar study using different methods in order to determine the state of a group of local organizations with a more in-depth such as using a qualitative research method so that it can reach the data load condition group organization areas in more detail. It is intended to find out the reasons why some of the area organizations still have low poly-culturalism in the diversity of the community.

\section{REFERENCES}

Akbar, A. (2018). Kohesivitas Tim dan Sikap Terhadap Kepemimpinan Wasit Sebagai Prediktor Kecenderungan Perilaku Agresif Pemain Sepakbola Profesional Indonesia. Tesis, 27-34.

Azwar, S. (2007). Metode Penelitian. Pustaka Pelajar.

Bachroni, M. (2011). Pelatihan Pembentukan Tim untuk Meningkatkan Kohesivitas Tim pada Kopertis V Yogyakarta. Jurnal Psikologi, 40-51.

Hanggardewa, A. A. (2018). Hubungan Kohesivitas Kelompok Dengan Komitmen Organisasii Pada Anggota Organisasi Mahasiswa Universitas Negeri Surabaya Periode 2017. Jurnal Psikologi, 2-4.

Hermawan, Y., \& Rstiana, E. (2019). Peningkatan produktivitas melalui kohesivitas kelompok dan revitalisasi kondisi. Jurnal Ilmu Administrasi, 51-56.

Hong, Y.-y., Zhan, S., Morris, M. W., \& Martinez, V. B. (2016). Multicultural Identity. Processes. Science Direct, 49-53.

Ibrahim, Z., Rahman, N. R., \& Johar, M. M. (2019). To Understand the Team Cohesiveness Teamwork Quality and Team Performance in Employee Performance in University. International Journal of Recent Technology and Engineering (IJRTE), 853-858.

Morris, M. W., Chiu, C.-y., \& Liu, Z. (2015). Annual Review of Psychology. Polycultural Psychology, 66, 631659. https://doi.org/10.1146/annurev-psych-010814015001

Pratama, S. Y. (2009). Pengaruh Kelompok Pada Anggota Kelompok Bomber. Skripsi, 9-22.

Putriantini, F. G. (2012). Semangat kerja ditinjau dari kohesivitas kelompok kerja pada mitra pemasaran di KSB regional V Yogyakarta. Jurnal Psikologi, 23-26. 
Rosenthal, L., \& Levy, S. R. (2010). The colorblind, multicultural, and poly-cultural ideological approaches to improving intergroup attitudes and relations. Social Issues and Policy Review, 4(1), 215-246.

Rosenthal, L., \& Levy, S. R. (2012). The relation between poly-culturalism and intergroup attitudes among racially and ethnically diverse adults. Cultural Diversity and Ethnic Minority Psychology, 1-16.

Rosenthal, L., Levy, S. R., Katser, M., \& Bazile, C. (2015). Polyculturalism and attitudes toward muslim Americans. Journal of Peace Psychology, 535-545.

Saidang, S. (2019). Pola Pembentukan Solidaritas Sosial dalam Kelompok Sosial antara pelajar. Jurnal Pendidikan, 122-126.

Sakdiah, H., \& Astuti, T. P. (2014). Hubungan antara kohesivitas kelompok dengan motivasi berprestasi pada atlet cabang olahraga beregu. Jurnal Psikologi, 12.
Santrock, J. W. (2012). LIFE-SPAN DEVELOPMENT. Erlangga.

Sugiyono. (2016). Metode Penelitian Kuantitatif, Kualitatif, dan RED. Alfabeta.

Tjipto, S., \& Bernardo, A. B. I. (2019). Constraints In The Meaning of Lay Theories of Culture in a Culturally Homogeneous Society: A Mixed-Methods Stdy on Multicultralism and Poly-culturalism in Wonosobo, Indonesia. Research Article Social Psychology, 1-23.

Umihani. (2019). Problematika Mayoritas dan Minoritas Dalam Interaksi Sosial Antar Umat Beragama. Skripsi, 248-268.

Wahidah, N. (2013). Hubungan antara Kohesivitas Kelompok Teman Sebaya dengan Perilaku Agresif pada Mahasiswa Fakultas Teknik Universitas Muslim Indonesia Makassar. Skripsi, 17-22. 